\section{AGRISOCIONOMICS}

Jurnal Sosial Ekonomi dan Kebijakan Pertanian
ISSN 2580-0566

EISSN 2621-9778

http://ejournal2.undip.ac.id/index.php/agrisocionomics

3(2): 131-149, November 2019

\title{
PENGENDALIAN KUALITAS PRODUK SELADA ROMAINE PADA SISTEM TANAM HIDROPONIK (STUDI KASUS DI UMKM KEBUN SAYUR, KOTA SURABAYA, JAWA TIMUR)
}

\author{
Quality Control of Romaine Lettuce Product on Hydroponic System \\ (Case Study in UMKM Kebun Sayur, Surabaya, East Java) \\ Nila Novianti, Heru Santoso Hadi Subagyo, Anisa Aprilia* \\ Jurusan Sosial Ekonomi, Fakultas Pertanian, Universitas Brawijaya \\ Jl. Veteran, Malang 65145 Jawa Timur, Indonesia \\ *Corresponding author: Anisa Aprilia \\ Email:anisa.asa@ub.ac.id
}

Diterima 25 Juni 2019, disetujui 7 november 2019

\begin{abstract}
ABSTRAK
Kualitas produk merupakan salah satu faktor yang diperhatikan oleh konsumen dalam membeli dan menggunakan sebuah produk. Namun, pada kenyataannya produk sayuran hidroponik khususnya Selada Romaine yang diproduksi oleh UMKM Kebun Sayur Surabaya memiliki kualitas yang kurang baik seperti adanya kecacatan produk. Sehingga penelitian ini dilakukan dengan tujuan menganalisis nilai kecacatan, faktor-faktor penyebab kecacatan dan harapan konsumen terhadap kualitas produk Selada Romaine. Penelitian dilakukan di UMKM Kebun Sayur Surabaya dengan menggunakan metode Statistical Quality Control (SQC) dan House of Quality (HoQ). Penelitian ini menggunakan teknik purposive judgment sampling untuk penentuan responden yang terdiri dari manajer perusahaan, dua orang karyawan produksi dan 40 konsumen UMKM Kebun Sayur Surabaya. Hasil penelitian menunjukkan bahwa: (1) Nilai kecacatan produk Selada Romaine hidroponik berada di luar batas kendali UCL (Upper Control Limit) dan LCL (Lower Control Limit), sehingga dikatakan tidak terkendali; (2) Faktor-faktor yang menyebabkan kecacatan produk yaitu faktor mesin, faktor manusia, faktor lingkungan dan faktor metode; (3) Harapan konsumen terhadap kualitas produk yaitu harga produk Rp 4.000 per ons; bentuk produk utuh; kesegaran produk yaitu fresh hasil panen; kebersihan produk sangat higienis; warna produk hijau segar; serta kemasan produk yaitu plastik terbuka seperti bucket bunga.
\end{abstract}

Kata Kunci: kualitas produk, pengendalian kualitas, harapan konsumen, Statistical Quality Control (SQC), House of Quality (HoQ)

\section{ABSTRACT}

The quality product is one of factor noticed by consumers for buying and using a product. However, the product of hydroponic especially Romaine Lettuce produced by UMKM Kebun Sayur Surabaya still has less quality as indicated by product defects. So, this research was carried out with aims to analyze defects value, the factors of defect and consumers hope on the product quality of Romaine Lettuce. This research conducted in UMKM Kebun Sayur Surabaya used Statistical Quality 
Control (SQC) dan House of Quality (HoQ) methods. This research used purposive judgment sampling technique for determining the respondents that consists of manager, two production employees, and forty consumers of UMKM Kebun Sayur Surabaya. The result showed: (1) defect value on Romaine Lettuce hydroponic product was in beyond the control of UCL (Upper Control Limit) and LCL (Lower Control Limit), and then said uncontrollable; (2) The factors which caused defect on products were machine, human, environment, and method; and (3) The consumers expect on product quality are $R p .4 .000$ per ounce; intect product form; the product was very fresh which resulted from harvest; it was very hygienic through washing process; it had fresh green product colored; and the package of product was unwrap as same as flower bucket.

Keywords: quality product, quality control, consumer expectation, Statistical Quality Control (SQC), House of Quality (HoQ)

\section{PENDAHULUAN}

Kualitas produk merupakan salah satu faktor yang diperhatikan oleh konsumen dalam membeli dan menggunakan sebuah produk. Adanya peningkatan pendidikan, kemampuan daya beli serta kepedulian konsumen terhadap nilai gizi telah menggugah kesadaran konsumen akan pentingnya suatu kualitas produk (Yuarini et al., 2015). Menurut Amanah (2017), konsumen akan bersedia mengeluarkan biaya yang lebih untuk memperoleh produk dengan kualitas yang baik. Kualitas produk yang baik tentunya dapat menciptakan kepuasan konsumen. Sehingga penting bagi perusahaan untuk menjaga dan meningkatkan kualitas produk yang dihasilkan.

Banyaknya usaha yang berdiri di Indonesia dalam bidang industri maupun jasa, telah menuntut adanya persaingan yang sangat ketat terhadap usaha sejenis. Menurut Weenas (2013), setiap usaha dituntut untuk memberikan perhatian penuh terhadap kualitas produk yang dihasilkan. Perusahaan yang memiliki produk dengan kualitas yang baik, akan mampu bersaing dan dapat mempertahankan eksistensi usaha. Sebagai upaya untuk menjaga kualitas produk agar sesuai standar, perusahaan memerlukan pengendalian kualitas dalam menjalankan proses produksi. Menurut Jacobs dan Chase (2015), pengendalian kualitas dilakukan untuk memberikan informasi mengenai kesesuaian antara barang yang diproduksi dengan spesifikasi desain produk. Apabila pengendalian kualitas tersebut dilakukan dengan baik, maka tujuan perusahaan dalam menciptakan produk berkualitas tinggi dapat tercapai.

Salah satu usaha bidang pertanian yang memiliki peluang besar untuk dikembangkan yaitu pada komoditas hortikultura khususnya sayuran. Menurut Nunes (2015), komoditas sayuran memiliki permintaan tinggi dan cenderung meningkat pada setiap tahunnya. Berdasarkan data Kementrian Pertanian (2015), produksi komoditas sayuran di Indonesia dari tahun 2009 hingga tahun 2014 selalu mengalami peningkatan. Produksi sayuran pada tahun 2009 sebesar 10.628.285 ton diketahui mengalami peningkatan pada tahun 2011 sebesar 10.871.224 ton, dan pada tahun 2014 juga mengalami peningkatan sebesar 11.918.571 ton. Besarnya nilai permintaan juga dapat dilihat dari besarnya tingkat konsumsi terhadap sayuran yaitu sebesar 82,9 \% (Badan Pusat Statistik, 2017). Selain itu, potensi sayuran juga dapat dilihat pada posisi ekspor dunia. Menurut Kementrian Pertanian (2018), bahwa pada tahun tahun 2017 ekspor sayuran seperti kubis, buncis dan selada air dapat menempati tiga urutan tertinggi yaitu 132.878 ton.

Saat ini banyak sekali usaha yang berkembang dalam menyediakan produk sayuran. Salah satunya yaitu UMKM di Surabaya yang memproduksi berbagai jenis produk sayuran selada dengan menggunakan sistem tanam hidroponik. Usaha hidroponik diketahui memiliki peluang yang cukup baik. 
Menurut Prasojo dalam berita online Unsurtani.com (2017), bahwa pangsa pasar sayuran hasil produksi secara hidroponik di Indonesia terus mengalami peningkatan sebesar 10\% hingga 20\%. Menurut Setiawan (2017), produk yang dihasilkan dari sistem tanam hidroponik memiliki kualitas yang lebih baik, karena lingkungan pertumbuhannya lebih terkontrol. Berdasarkan hasil survei, permasalahan yang sering timbul pada proses produksi yaitu adanya kecacatan produk. Kecacatan produk hampir terjadi pada semua jenis sayuran salah satunya yaitu Selada Romaine, sehingga produk mengalami penurunan kualitas. Hal tersebut menjadi perhatian bagi peneliti untuk meneliti pengendalian kualitas pada produk sayuran.

Beberapa fenomena juga mengungkapkan bahwa kualitas produk merupakan hal yang penting untuk diperhatikan. Berdasarkan berita online Kontan.co.id (2018), nilai ekspor produk pertanian Indonesia pada Agustus 2018 mengalami penurunan hingga 20,98\%. Nilai ekspor menurun dari US\$ 381,2 juta pada Agustus 2017 menjadi US\$ 301,2 juta pada Agustus 2018 (BPS, 2018). Salah satu penyebab turunnya nilai ekspor yaitu rendahnya kualitas produk pertanian asal Indonesia. Fenomena lain yang terjadi yaitu menurut Yuarini et al., (2015) peningkatan pendidikan, kemampuan daya beli dan kepedulian nilai gizi telah menggugah kesadaran konsumen akan pentingnya kualitas bahan makanan. Hal tersebut disertai pula dengan pergeseran paradigma terhadap kepentingan kesehatan dengan pengurangan peran pupuk dan pestisida dalam bahan makanan, khususnya pada sayuran organik yang berkualitas. Sehingga pengendalian kualitas penting dilakukan untuk memenuhi harapan konsumen.

Berdasarkan beberapa fenomenafenomena di atas, penelitian mengenai pengendalian kualitas produk sayuran dikatakan penting untuk dilakukan. Penelitian mengenai pengendalian kualitas dengan menganalisis kecacatan produk dan harapan konsumen dilakukan di suatu lokasi yang sama, sehingga berbeda dengan penelitian sebelumnya yang meneliti pengendalian kualitas hanya dari sisi kerusakan produknya saja atau konsumen saja dan dilakukan pada lokasi yang berbeda.

Berdasarkan uraian tersebut, maka penelitian ini dilakukan dengan tujuan untuk menganalisis nilai kecacatan produk Selada Romaine hidroponik dalam batas kendali pelaksanaan pengendalian kualitas, faktorfaktor yang menyebabkan kecacatan produk Selada Romaine hidroponik serta harapan konsumen terhadap kualitas produk Selada Romaine hidroponik UMKM Kebun Sayur Surabaya.

\section{METODE PENELITIAN}

\section{Pendekatan Penelitian}

Jenis penelitian yang digunakan dalam penelitian ini yaitu penelitian kuantitatif. Menurut Sugiyono (2018) metode kuantitatif merupakan metode dengan menggunakan data penelitian berupa angka-angka dan analisis menggunakan statistik, dan dengan tujuan untuk menguji hipotesis yang telah ditetapkan. Analisis kuantitatif dalam penelitian ini digunakan untuk melalukan perhitungan proporsi kecacatan, nilai kecacatan produk, nilai bobot atribut produk, nilai kontribusi, analisis penyebab kecacatan dan beberapa analisis lainnya.

\section{Penentuan Lokasi dan Waktu Penelitian}

Penelitian dilakukan di UMKM Kebun Sayur Surabaya yang berlokasi di Jalan Gayung Kebonsari XI/15 Ketintang Injoko Kota Surabaya Jawa Timur. Teknik penentuan lokasi penelitian dilakukan secara purposive. Teknik purposive digunakan dengan alasan pemilihan lokasi dipilih secara sengaja dengan menggunakan pertimbangan tertentu. Pemilihan lokasi tersebut dengan mempertimbangkan bahwa UMKM Kebun Sayur Surabaya merupakan salah satu perusahaan yang bergerak di bidang tanaman hidroponik 
dan mampu mendistribusikan produk kepada beberapa restoran, hotel maupun supermarket. Selain itu, adanya permasalahan pada produk sayuran khususnya Selada Romaine yang dihasilkan oleh perusahaan masih diketahui terdapat beberapa kecacatan, sehingga penentuan lokasi dilakukan untuk meneliti kualitas produk Selada Romaine pada UMKM Kebun Sayur Surabaya. Kegiatan penelitian dilaksanakan dalam waktu dua bulan. Perhitungan waktu penelitian terhitung dari Bulan Desember 2018 sampai Bulan Januari 2019.

\section{Teknik Penentuan Sampel}

Responden dalam penelitian ini terdiri dari manajer perusahaan, dua karyawan bagian produksi, dan konsumen produk Selada Romaine hidroponik UMKM Kebun Sayur Surabaya yang dilakukan dengan wawancara. Penentuan responden dilakukan dengan teknik purposive judgment sampling. Menurut Sekaran (2003), judgment sampling merupakan desain non probability purposive sampling, di mana sampel atau subjek dipilih berdasarkan kemampuan individu untuk memberikan informasi khusus yang dibutuhkan oleh peneliti. Jumlah responden yang digunakan dalam penelitian ini yaitu sebanyak 40 orang. Menurut Sugiyono (2018), pengukuran yang layak untuk dijadikan sampel dalam sebuah penelitian yaitu antara 30 sampai 500. Kriteria konsumen yang dikehendaki sebagai responden dalam penelitian yaitu konsumen akhir produk Selada Romaine hidroponik, berjenis kelamin perempuan, memiliki usia di atas 17 tahun, sebelumnya pernah membeli produk Selada Romaine hidroponik minimal satu kali serta mau atau bersedia dan memiliki waktu luang untuk menjadi responden.

\section{TEKNIK ANALISIS DATA}

\section{Statistical Quality Control (SQC)}

Pengendalian kualitas statistik atau Statistical Quality Control (SQC) merupakan metode dengan menggunakan sejumlah teknik berbeda yang didesain untuk mengevaluasi kualitas dari segi kesesuaian, yaitu bagaimana kesesuaian dengan spesifikasi yang telah ditetapkan oleh suatu perusahaan (Jacobs dan Chase, 2015). Menurut Stevenson dan Chuong (2014), salah satu alat yang penting dalam SQC adalah bagan kendali yang memiliki batas atas dan batas bawah. Pengendalian kualitas secara statistik memiliki tujuh alat statistik, namun pada penelitian ini hanya menggunakan lima alat statistik yaitu diagram alir (flow chart), lembar pemeriksaan (check sheet), diagram pareto, peta kendali ( $p$ chart), dan diagram sebab akibat (fishbone diagram). Adapun langkah-langkahnya yaitu:

1. Membuat diagram alir proses produksi Selada Romaine.

2. Mengumpulkan data produksi dan kecacatan produk Selada Romaine periode Desember 2017 sampai Desember 2018.

3. Membuat diagram pareto untuk jenis kecacatan produk Selada Romaine.

4. Membuat peta kendali produk Selada Romaine hidroponik dengan tahapan:

a. Menghitung persentase kerusakan

$$
P=\frac{n p}{n}
$$

Keterangan:

np : jumlah gagal dalam sub grup

$\mathrm{n}$ : jumlah yang diperiksa dalam sub grup (hari ke-)

b. Menghitung garis pusat atau central line (CL)

$$
C L=\bar{p}=\frac{\sum n p}{\sum n}
$$

Keterangan:

$\sum \mathrm{np}$ : jumlah total yang rusak

$\sum \mathrm{n}$ : jumlah total yang diperiksa

c. Menghitung batas kendali atas upper control limit (UCL)

$$
U C L=\bar{p}+3=\left(\sqrt{\frac{\bar{p}(1-\bar{p})}{n}}\right)
$$

Keterangan: 
$\bar{p} \quad$ : rata-rata ketidaksesuaian produk n : jumlah produksi

d. Menghitung batas kendali bawah atau lower control limit (LCL)

$U C L=\bar{p}-3=\left(\sqrt{\frac{\bar{p}(1-\bar{p})}{n}}\right)$

Keterangan:

$\bar{p} \quad$ : rata-rata ketidaksesuaian produk

n : jumlah produksi

5. Mencari faktor penyebab kecacatan dengan diagram sebab akibat.

\section{House of Quality (HoQ)}

Menurut Heizer dan Render (2016), House of Quality (HoQ) atau yang biasa disebut dengan rumah kualitas merupakan salah satu alat Quality Function Deployment (QFD). Menurut Wijaya (2018), House of Quality (HoQ) merupakan alat utama yang digunakan untuk pengukuran struktur QFD. HoQ adalah sebuah teknik grafis yang digunakan untuk mendefinisikan hubungan antara keinginan atau harapan konsumen dengan produk atau jasa. Penjelasan dari tahapan matriks perencanaan antara lain:

1. Identifikasi kebutuhan konsumen (matriks what's)

Matrik kebutuhan konsumen berisi permintaan konsumen dalam sebuah kualitas produk. Atribut produk yang digunakan yaitu harga, bentuk, kesegaran, kebersihan, warna, dan kemasan produk.

2. Matriks perencanaan (planning matriks)

a. Penentuan tingkat kepentingan (importance in customer)

b. Penentuan tingkat kepuasan konsumen (costumer satisfication performance)

c. Penentuan nilai target (goal) yang diperoleh dari perbandingan nilai terbaik tingkat kepuasan konsumen.

d. Titik penjualan (sales point)

Skala yang digunakan yaitu 1,0 jika atribut memberikan daya tarik lemah, 1,2 jika daya tarik sedang dan 1,5 jika daya tarik kuat. e. Menghitung ratio perbaikan (improvement ratio)

$$
I R=\frac{\text { goal }}{\text { customer satisfaction performance }}
$$

f. Menghitung bobot (row weight)

$\mathrm{RW}=$ importance to customer $\mathrm{x} \mathrm{IR}$ $\mathrm{x}$ sales point

g. Menghitung bobot normal (normalized raw weight)

$$
N R W=\frac{\text { net weight }}{\sum \text { raw weight }}
$$

3. Respon teknik (matriks how's)

Respon teknik berasal dari hasil wawancara dengan manajer UMKM Kebun Sayur Surabaya. Wawancara dilakukan untuk mengetahui posisi produk dalam hal kepuasan konsumen.

4. Matriks hubungan (relationship matrix)

Matriks hubungan merupakan hubungan antara respon teknik dengan keseluruhan komponen. Simbol yang digunakan yaitu: $\bullet=9=$ simbol hubungan kuat; $\circ=3=$ simbol hubungan sedang; $\Delta=1=$ simbol hubungan lemah; $0=$ tidak ada hubungan .

5. Korelasi teknik (technical correlation

Korelasi teknik merupakan matriks yang mengidentifikasi apakah respon teknik yang saling mendukung atau saling megganggu dalam desain produk

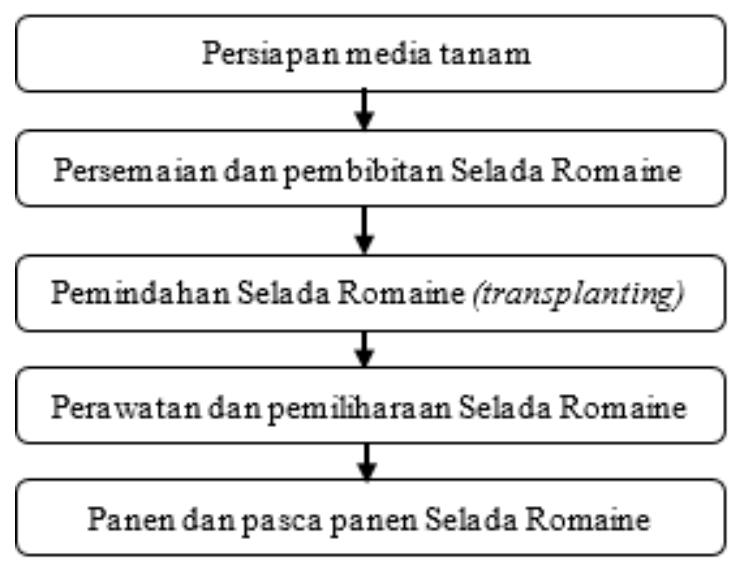

Ilustrasi 1. Diagram Alir Proses Produksi Selada Romaine Hidroponik

Sumber: Data Primer Diolah (2019) 
dengan simbol yang menyatakan berpengaruh positif atu negatif.

6. Matriks teknik (technical matrix)

a. Prioritas dan kontribusi

Prioritas $=\sum$ (bobot normal $\mathrm{x}$ nilai relationship matrix)

b. Benchmarking

$B=\frac{\sum(\text { Tk kepuasan }) x \text { Hubungan what 's } s \wedge \text { how's }}{\sum \text { Hubungan what's } \wedge \text { how's }}$

c. Targeting

Merupakan tujuan yang ingin dicapai oleh usaha UMKM Kebun Sayur Surabaya.

7. Penyusunan House of Quality (HoQ)

\section{HASIL DAN PEMBAHASAN}

\section{Analisis Nilai Kecacatan Produk Selada Romaine Hidroponik}

Metode yang digunakan untuk menganalisis nilai kecacatan dalam batas kendali yaitu Statistical Quality Control (SQC) dengan alat analisis diagram alir, lembar pemeriksaan, diagram pareto dan peta kendali.

\section{1) Diagram Alir (flow chart)}

Proses produksi Selada Romaine hidroponik di UMKM Kebun Sayur Surabaya memiliki 5 tahapan. Tahap proses produksi dapat dilihat pada Ilustrasi 1.

\section{2) Lembar Pemeriksaan (check sheet)}

Kecacatan yang terjadi pada produk Selada Romaine digolongkan menjadi dua jenis yaitu kondisi daun cacat dan akar terlepas dari tanaman. Kondisi daun cacat bisa dikategorikan sebagai daun cacat yaitu daun berlubang, kekuningan, daun terdapat bercak coklat. Adapun hasil pengumpulan data melalui lembar pemeriksaan (check sheet) dapat dilihat pada Tabel 1.

Berdasarkan data Tabel 1, pada periode Desember 2017 sampai dengan Desember 2018 diperoleh hasil produksi sebesar $4.069 \mathrm{~kg}$. Total kecacatan pada dua jenis yaitu sebesar $1.024 \mathrm{~kg}$, dengan hasil presentase kecacatan sebesar $338.837 \%$. Jumlah produksi terbesar yaitu pada Bulan Juli

Tabel 1. Lembar Pemeriksaan Kecacatan Produk Selada Romaine UMKM Kebun Sayur Surabaya Periode Desember 2017 sampai Desember 2018

\begin{tabular}{cccccc}
\hline \multirow{2}{*}{ Bulan } & $\begin{array}{c}\text { Produksi } \\
(\mathrm{kg})\end{array}$ & $\begin{array}{c}\text { Kondisi daun } \\
\text { cacat }\end{array}$ & $\begin{array}{c}\text { Akar terlepas dari } \\
\text { tanaman }\end{array}$ & $\begin{array}{c}\text { Total Kecacatan } \\
(\mathrm{kg})\end{array}$ & $\begin{array}{c}\text { Presentase } \\
\text { Kecacatan }(\%)\end{array}$ \\
\hline Desember & 247 & 84,15 & 14,85 & 99 & 40,081 \\
Januari & 279 & 97,75 & 17,25 & 115 & 41,219 \\
Februari & 273 & 87,55 & 15,45 & 103 & 37,729 \\
Maret & 287 & 90,95 & 16,05 & 107 & 37,282 \\
April & 310 & 41,65 & 7,35 & 49 & 15,806 \\
Mei & 343 & 41,65 & 7,35 & 49 & 14,286 \\
Juni & 340 & 43,35 & 7,65 & 51 & 15,000 \\
Juli & 354 & 45,05 & 7,95 & 53 & 14,972 \\
Agustus & 346 & 49,3 & 8,7 & 58 & 16,763 \\
September & 315 & 68,85 & 12,15 & 81 & 25,714 \\
Oktober & 327 & 67,15 & 11,85 & 79 & 24,159 \\
November & 329 & 53,55 & 9,45 & 63 & 19,149 \\
Desember & 319 & 99,45 & 17,55 & 117 & 36,677 \\
\hline Total & 4.069 & 870,4 & 153,6 & 1.024 & 338,837 \\
Rata-rata & 313 & 66,954 & 11,815 & 78,769 & 26,064 \\
\hline
\end{tabular}

Sumber: Hasil Olahan Data (2019) 
sebesar $354 \mathrm{~kg}$, sedangkan jumlah kecacatan terbesar yaitu pada Bulan Desember 2018 sebesar $117 \mathrm{~kg}$ dan Bulan Januari 2018 sebesar $115 \mathrm{~kg}$. Sedangkan untuk presentase kececatan terbesar yaitu pada Bulan Januari 2018 sebesar 41,219 \%. Kecacatan Selada Romaine pada Bulan Desember, Januari, Februari dan Maret terbilang cukup besar yaitu $35-41 \%$. Tingginya kecacatan produk pada bulan-bulan tersebut dikarenakan sedang terjadi musim hujan yang dapat meningkatkan serangan penyakit mata kodok pada produk.

\section{3) Diagram Pareto}

Diagram pareto digunakan untuk mengidentifikasi serta menyeleksi masalah utama atau jenis kecacatan yang terjadi untuk peningkatan kualitas dari paling besar ke yang paling kecil. Adapun diagram pareto yang dihasilkan disajikan pada Ilustrasi 2.

Diagram pareto kecacatan Selada

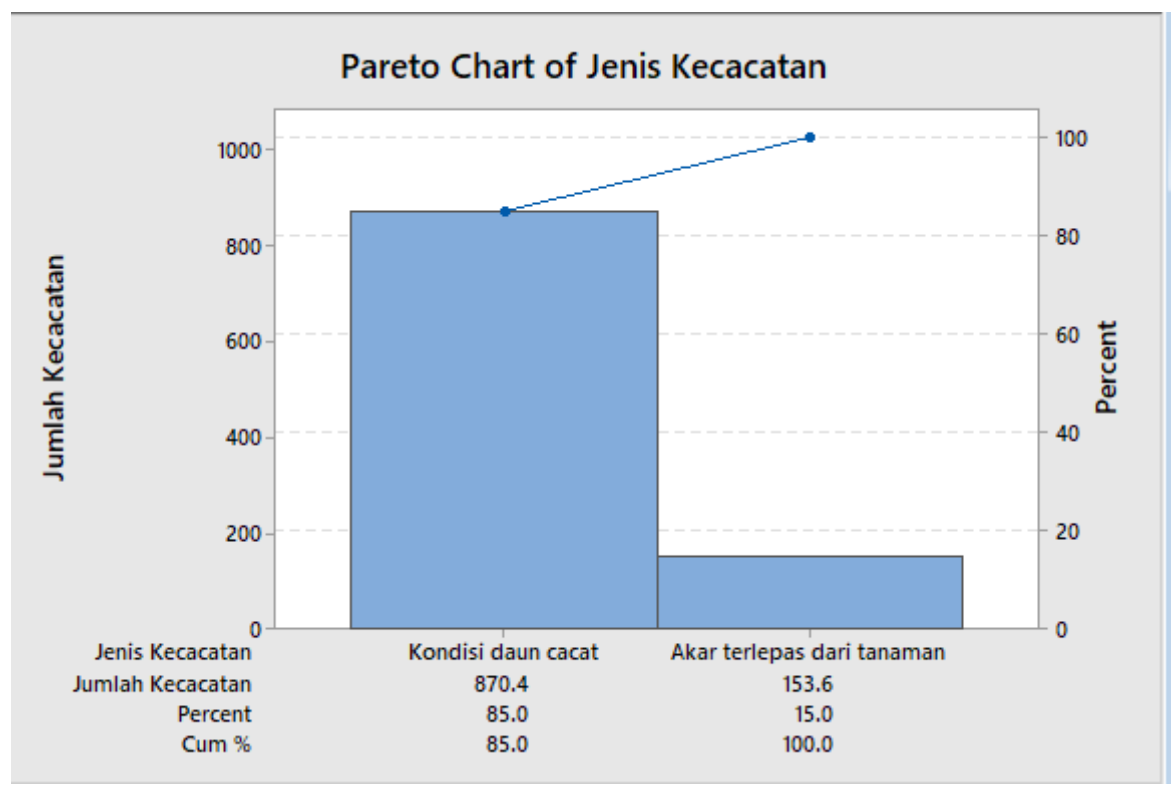

Ilustrasi 2. Diagram Pareto Kecacatan Selada Romaine UMKM Kebun Sayur Surabaya Sumber: Data Primer Diolah (2019)

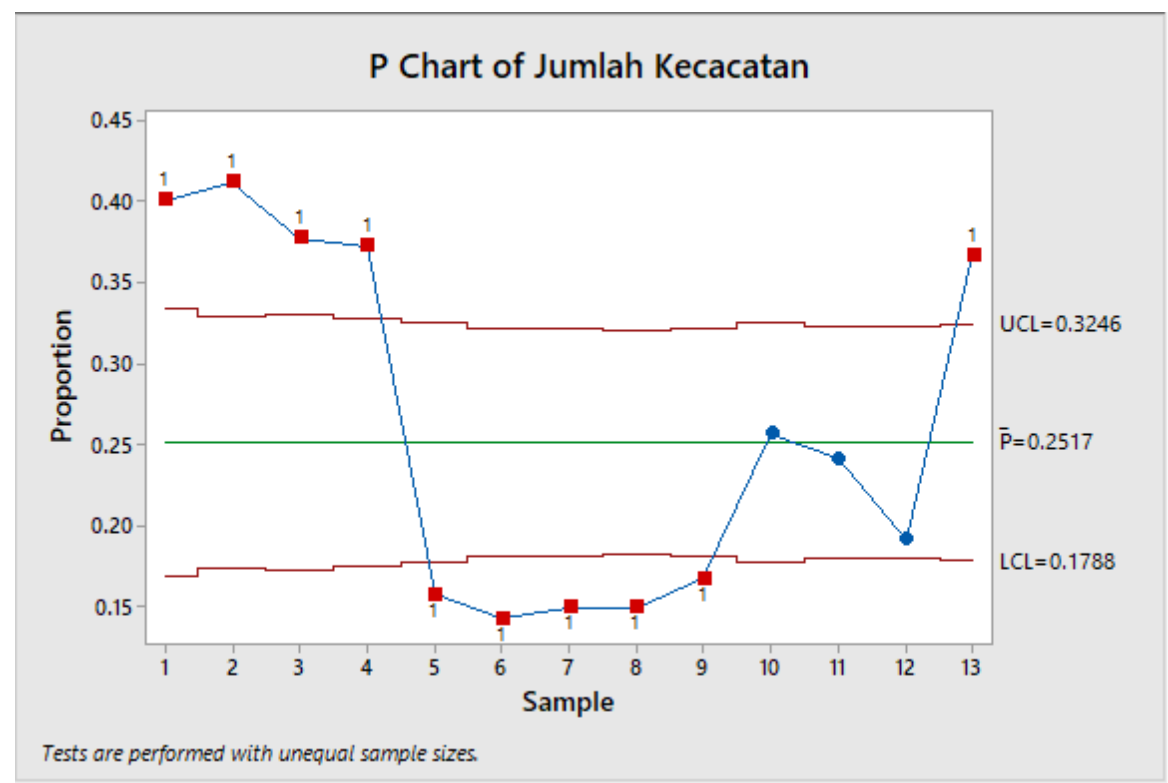

Ilustrasi 3. Grafik Peta Kendali Kecacatan Selada Romaine UMKM Kebun Sayur Surabaya Sumber: Data Primer Diolah (2019) 
Tabel 2. Perhitungan Batas Kendali Periode Desember 2017 sampai Desember 2018

\begin{tabular}{|c|c|c|c|c|c|c|c|}
\hline Bulan & $\begin{array}{c}\text { Jumlah } \\
\text { Produksi } \\
(\mathrm{kg})\end{array}$ & $\begin{array}{c}\text { Total Kecacatan } \\
(\mathrm{kg})\end{array}$ & $\begin{array}{c}\text { Presetase } \\
\text { Kecacatan } \\
(\%)\end{array}$ & $\mathrm{P}$ & $\mathrm{CL}$ & UCL & LCL \\
\hline Desember & 247 & 99 & 40,081 & 0,401 & 0,252 & 0,334 & 0,169 \\
\hline Januari & 279 & 115 & 41,219 & 0,412 & 0,252 & 0,329 & 0,174 \\
\hline Februari & 273 & 103 & 37,729 & 0,377 & 0,252 & 0,331 & 0,173 \\
\hline Maret & 287 & 107 & 37,282 & 0,373 & 0,252 & 0,329 & 0,175 \\
\hline April & 310 & 49 & 15,806 & 0,158 & 0,252 & 0,326 & 0,178 \\
\hline Mei & 343 & 49 & 14,286 & 0,143 & 0,252 & 0,322 & 0,182 \\
\hline Juni & 340 & 51 & 15,000 & 0,150 & 0,252 & 0,322 & 0,182 \\
\hline Juli & 354 & 53 & 14,972 & 0,150 & 0,252 & 0,321 & 0,183 \\
\hline Agustus & 346 & 58 & 16,763 & 0,168 & 0,252 & 0,322 & 0,182 \\
\hline September & 315 & 81 & 25,714 & 0,257 & 0,252 & 0,325 & 0,179 \\
\hline Oktober & 327 & 79 & 24,159 & 0,242 & 0,252 & 0,324 & 0,180 \\
\hline November & 329 & 63 & 19,149 & 0,191 & 0,252 & 0,324 & 0,180 \\
\hline Desember & 319 & 117 & 36,677 & 0,367 & 0,252 & 0,325 & 0,179 \\
\hline Total & 4.069 & 1.024 & 338,837 & 3,388 & 3,275 & 4,233 & 2,318 \\
\hline Rata-rata & 313 & 78,769 & 26,064 & 0,261 & 0,252 & 0,325 & 0,178 \\
\hline
\end{tabular}

Sumber: Hasil Olahan Data (2019)

Romaine pada Ilustrasi 2, dapat dilihat bahwa kecacatan produk yang paling dominan yaitu kondisi daun cacat sebesar $870,4 \mathrm{~kg}$ dari keseluruhan kejadian. Ditemukan sebesar $85 \%$ kejadian didominasi oleh banyaknya daun cacat yang terjadi pada setiap produksi hingga sortasi. Kecacatan kedua yaitu akar terlepas dari tanaman dengan jumlah 153,6 kg. Ditemukan sebesar 15\% kejadian disebabkan oleh banyaknya jumlah akar terlepas dari tanaman. Adanya kejadian akar terlepas dari tanaman menyebabkan tanaman tidak bisa dipasarkan karena tidak sesuai dengan standar perusahaan.

\section{4) Peta Kendali}

Tabel 2 menunjukkan hasil perhitungan peta kendali $p$ yang selengkapnya pada periode Bulan Desember 2017 sampai Bulan Desember 2018.

Berdasarkan peta kendali pada Ilustrasi 3, data produksi Selada Romaine Bulan Desember 2017 sampai Desember 2018 yang diperoleh tidak seluruhnya berada dalam batas kendali. Terdapat 3 titik berada dalam batas kendali atau berada di dalam UCL dan LCL. Terdapat 5 titik berada diluar

batas kendali atau di atas garis UCL dan terdapat 5 titik berada dibawah garis LCL. Hasil ini menginformasikan bahwa proses produksi yang dilakukan tidak terkendali. Titik yang berada di atas garis UCL dikatakan tidak terkendali karena terdapat nilai kecacatan yang tinggi dibandingkan dengan titik pada bulan lainnya. Sedangkan titik yang berada di bawah garis LCL mengindikasikan bahwa telah ada perubahan proses. Menurut Krajewski et al. (2013), ketika titik berada di luar garis LCL, peta kendali menunjukkan bahwa ada sesuatu yang baik terjadi atau nilai kecacatan rendah dibandingkan dengan titik pada bulan lainnya. Namun adanya titik yang berfluktuasi menunjukkan bahwa proses pengendalian kualitas Selada Romaine mengalami penyimpangan atau belum dilakukan dengan baik.

Titik yang berada di atas garis UCL dengan nilai kecacatan tertinggi terjadi pada Bulan Desember 2017 sampai Bulan Maret 2018, hal tersebut dikarenakan sedang terjadi musim hujan yang dapat meningkatkan serangan penyakit mata kodok. Selanjutnya jumlah kecatatan terjadi penurunan yang cukup besar pada Bulan April 2018 sampai 
Bulan Agustus 2018. Hal tersebut dikarenakan proses produksi Selada Romaine sedang berada dalam kondisi cuaca yang normal atau musim kemarau sehingga serangan penyakit mata kodok diketahui menurun. Terjadi peningkatan kecacatan kembali pada Bulan September 2018 sampai Bulan November 2018. Hal tersebut dikarenakan proses produksi Selada Romaine berada pada musim kemarau puncak sehingga terdapat serangan hama ulat yang cukup besar. Meskipun demikian kecacatan yang terjadi pada bulan tersebut diketahui masih dalam batas kendali. Kemudian kecacatan mengalami peningkatan hingga berada di luar batas kendali pada Bulan Desember 2018. Hal tersebut juga dikarenakan sedang terjadi musim hujan. Sehingga dapat disimpulkan bahwa jumlah kecacatan produk Selada Romaine yang terjadi sebagian besar disebabkan oleh faktor lingkungan atau cuaca.

\section{Analisis Faktor-faktor yang Menyebabkan Kecacatan Produk Selada Romaine Hidroponik}

Alat analis diagram sebab akibat atau fishbone diagram pada metode Statistical Quality Control (SQC) digunakan untuk menganalisis hambatan atau permasalahan yang terjadi dalam proses produksi Selada Romaine sehingga mengakibatkan munculnya kecacatan produk. Diagram sebab akibat dapat membantu menganalisis penyebab adanya kerusakan yang dapat berasal dari materiall (bahan baku), machine (mesin atau teknologi), man (manusia atau karyawan), method (metode atau proses produksi), dan environment (lingkungan). Setelah menentukan jenis kerusakan yang menjadi prioritas penyelesaian masalah, maka langkah selanjutnya yaitu menentukan perbaikan untuk meminimalisir adanya kecacatan yang sama. Penggunaan diagram sebab akibat untuk menelusuri penyebab atau permasalahan dan akar permasalahan terkait adanya kecacatan produk Selada Romaine disajikan pada Ilustrasi 4 dan Ilustrasi 5.

Setelah menemukan beberapa penyebab kecacatan pada produk Selada Romaine hidroponik, langkah selanjutya yaitu menentukan usulan perbaikan kualitas produk. Tabel 3 menyajikan usulan produk Selada Romaine.

\section{Analisis Harapan Konsumen terhadap Kualitas Produk Selada Romaine Hidroponik}

Analisis harapan konsumen dilakukan dengan menggunakan alat House of Quality (HoQ). Analisis House of Quality (HoQ) dilakukan dengan beberapa tahapan, diantaranya yaitu:

\section{1) Identifikasi Kebutuhan Konsumen}

Berdasarkan hasil analisis diketahui harapan konsumen terhadap produk Selada Romaine hidroponik yaitu harga produk Rp 4.000 per ons; bentuk produk yaitu utuh atau tidak terdapat daun bercak coklat, berlubang, kuning dan akar terlepas dari tanaman; kesegaran produk yaitu sangat segar atau fresh hasil panen; kebersihan produk yaitu sangat higienis melalui proses pencucian; warna produk yaitu hijau segar atau tidak terlalu tua dan muda; serta kemasan produk yaitu plastik terbuka seperti bucket bunga.

\section{2) Matriks Perencanaan}

a. Tingkat kepentingan konsumen

Tingkat kepentingan konsumen terhadap Selada Romaine hidroponik dapat diukur menggunakan skala likert. Skala 1 mewakili atribut yang dianggap sangat tidak penting, skala 2 tidak penting, skala 3 cukup penting, skala 4 penting dan skala 5 sangat penting. Tabel 4 menyajikan hasil dari tingkat kepentingan pada masingmasing atribut.

Berdasarkan Tabel 4 dapat diketahui bahwa terdapat 17 responden memilih atribut harga, 16 responden memilih atribut 


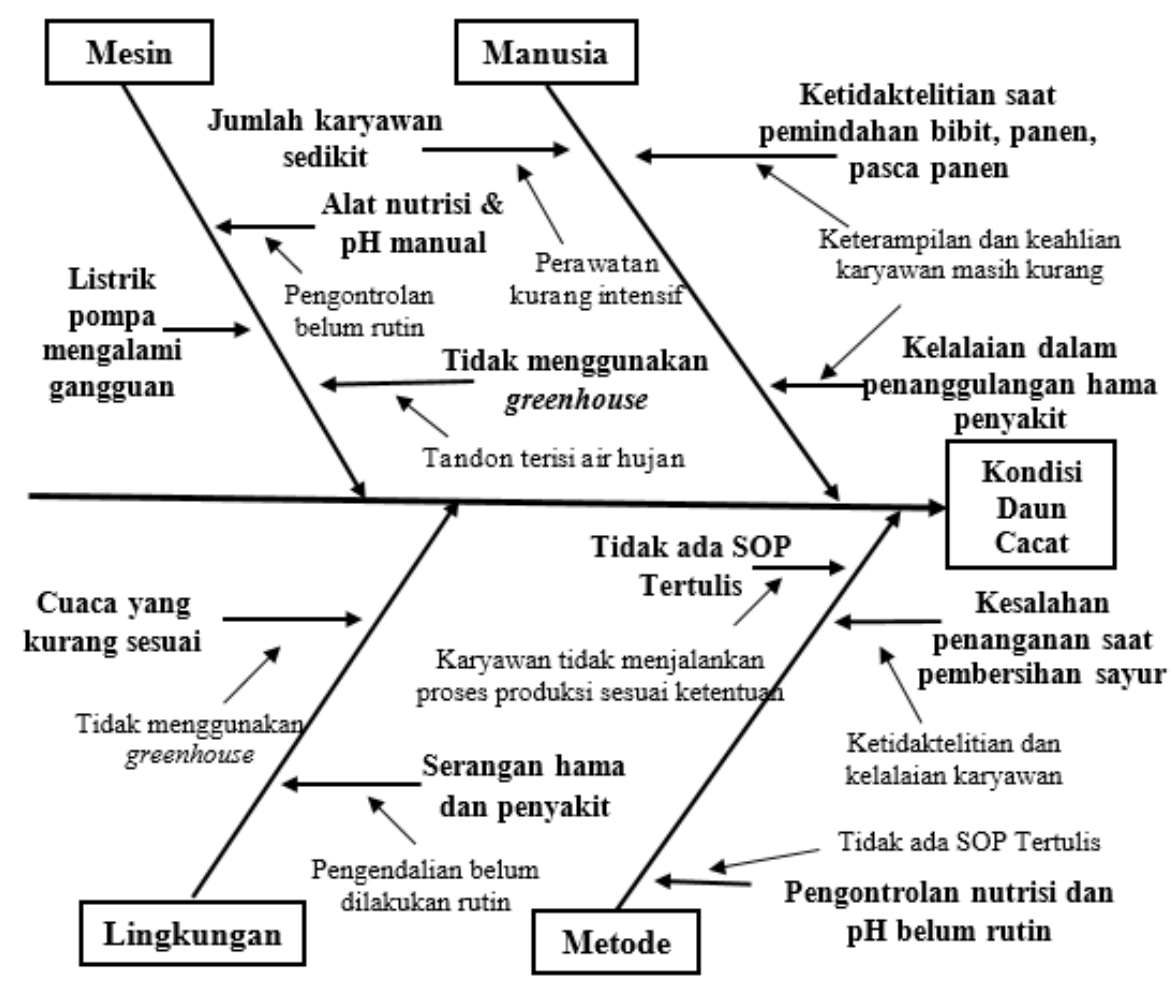

Ilustrasi 4. Diagram Sebab Akibat Kecacatan Kondisi Daun Cacat Sumber: Data Primer Diolah (2019)

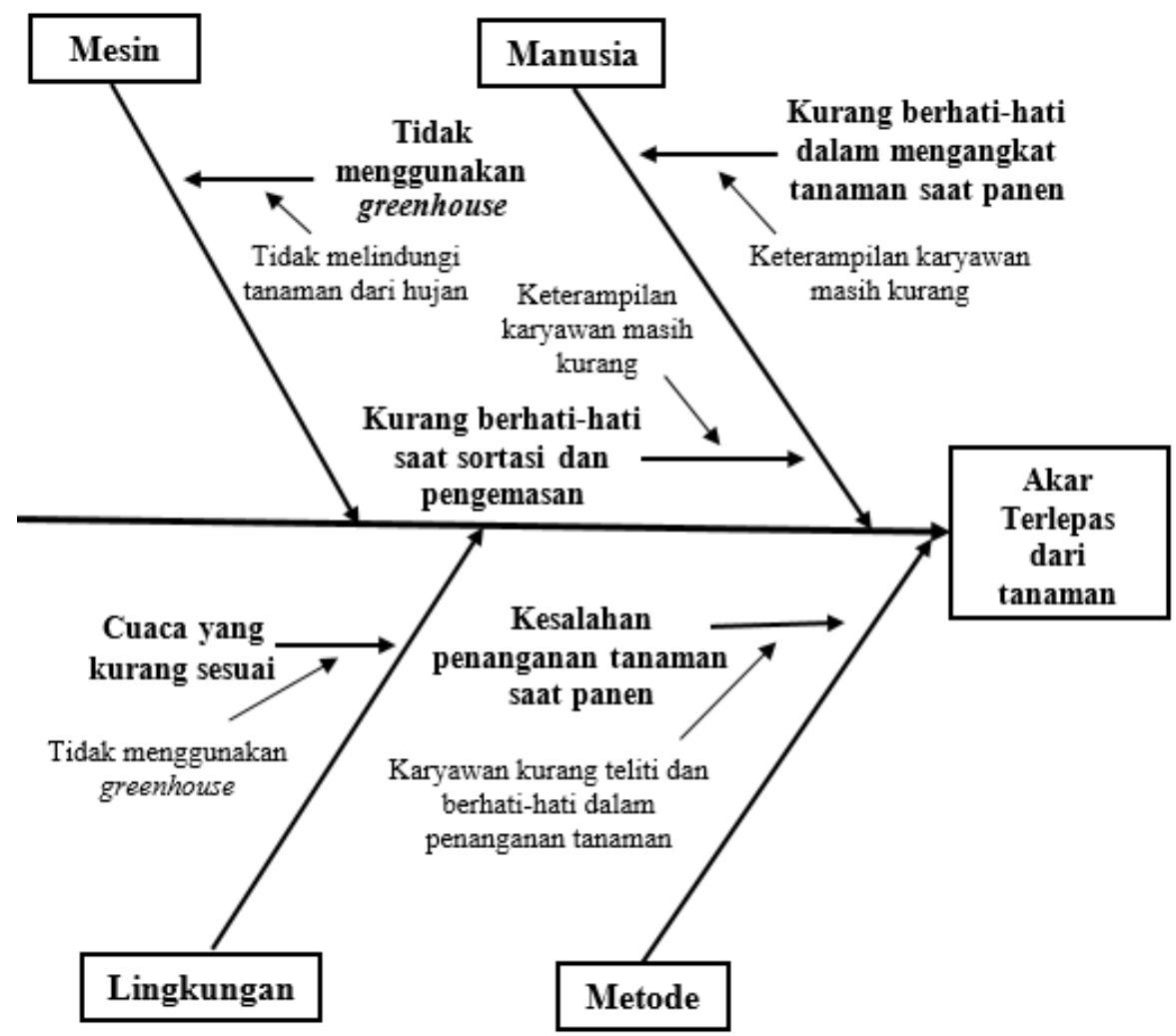

Ilustrasi 5. Diagram Sebab Akibat Kecacatan Akar Terlepas dari Tanaman Sumber: Data Primer Diolah (2019) 
Tabel 3. Usulan Perbaikan untuk Mengatasi Penyebab Kecacatan Selada Romaine Hidroponik

\begin{tabular}{|c|c|c|c|}
\hline & $\begin{array}{c}\text { Faktor } \\
\text { Penyebab }\end{array}$ & Permasalahan & Usulan Perbikan \\
\hline 1. & Mesin & $\begin{array}{l}\text { a. Tidak menggunakan } \\
\text { greenhouse } \\
\text { b. Alat } \mathrm{pH} \text { dan nutrisi } \\
\text { manual } \\
\\
\text { c. Listrik pompa } \\
\text { mengalami } \\
\text { gangguan }\end{array}$ & $\begin{array}{l}\text { a. Perusahaan mengusahakan dalam pembuatan } \\
\text { greenhouse, minimal tutupan yang sudah } \\
\text { digunakan pada bagian persemaian. } \\
\text { b. Apabila penggunaan teknologi yang modern } \\
\text { masih belum memungkinkan, maka perusahaan } \\
\text { dapat membuat SOP tertulis untuk ketetapan } \\
\text { pengontrolan nutrisi dan pH. } \\
\text { c. Memiliki cadangan genset yang digunakan pada } \\
\text { saat listrik mati. }\end{array}$ \\
\hline 2. & Manusia & $\begin{array}{l}\text { a. Jumlah karyawan } \\
\text { sedikit } \\
\text { b. Ketidaktelitian saa } \\
\text { pemindahan bibit, } \\
\text { panen dan pasca } \\
\text { panen } \\
\text { c. Kelalaian dalam } \\
\text { penanggulangan } \\
\text { hama dan penyakit } \\
\text { d. Kurang berhati-hat } \\
\text { dalam mengangka } \\
\text { tanaman saat panen, } \\
\text { sortasi dan } \\
\text { pengemasan }\end{array}$ & $\begin{array}{l}\text { a. Menambah karyawan pada bagian produksi. } \\
\text { b. Mengadakan pelatihan hidroponik secara berkala } \\
\text { (tiga bulan sekali), serta memantau dan } \\
\text { membimbing karyawan saat bekerja di lapang. } \\
\text { c. Melakukan kegiatan perawatan lahan sesuai } \\
\text { dengan peraturan budidaya yang ada, serta lebih } \\
\text { mendisiplinkan karyawan untuk lebih peduli } \\
\text { dengan tanaman. } \\
\text { d. Memberikan bimbingan kepada karyawan untuk } \\
\text { melakukan panen, sortasi dan pengemasan } \\
\text { dengan benar dan hati-hati. }\end{array}$ \\
\hline 3. & Lingkungan & $\begin{array}{l}\text { a. Cuaca yang kurang } \\
\text { sesuai } \\
\text { b. Serangan hama dan } \\
\text { penyakit }\end{array}$ & $\begin{array}{l}\text { a. Membangun greenhouse, serta menambahn } \\
\text { semaian saat musim hujan. } \\
\text { b. Melakukan pengendalian hama dan penyakit } \\
\text { secara preventif dengan pestisida alami yang } \\
\text { telah terdaftar di Deptan. }\end{array}$ \\
\hline 4. & Metode & $\begin{array}{l}\text { a. Tidak ada SOF } \\
\text { (Standar } \\
\text { Operasional } \\
\text { Prosedur) secara } \\
\text { b. tertulis } \\
\text { Kesalahan } \\
\text { penanganan saa } \\
\text { c. pembersihan sayur } \\
\text { Pengontrolan nutris } \\
\text { dan pH belum rutin }\end{array}$ & $\begin{array}{l}\text { a. Membuat SOP secara tertulis, agar proses } \\
\text { produksi memiliki standar yang tetap. } \\
\text { b. Melakukan bimbingan dalam penanganan sayur } \\
\text { yang benar. } \\
\text { c. Mendisiplinkan kegiatan pengontrolan pH dan } \\
\text { nutrisi secara rutin sesuai jadwal. }\end{array}$ \\
\hline
\end{tabular}

Sumber: Data Primer Diolah (2019) 
Tabel 4. Tingkat Kepentingan Konsumen Terbanyak pada Selada Romaine Hidroponik UMKM Kebun sayur Surabaya

\begin{tabular}{lccc}
\hline $\begin{array}{c}\text { Atribut } \\
\text { Selada } \\
\text { Romaine }\end{array}$ & $\begin{array}{c}\text { Tingkat } \\
\text { Kepentingan (orang) }\end{array}$ & $\begin{array}{c}\text { Jumlah } \\
\text { Persen- } \\
\text { tase (\%) }\end{array}$ \\
\hline Harga & 4 & 17 & 42,5 \\
Bentuk & 4 & 16 & 40,0 \\
Kesegaran & 5 & 26 & 65,0 \\
Kebersihan & 5 & 29 & 72,5 \\
Warna & 4 & 20 & 50,0 \\
Kemasan & 4 & 21 & 52,5 \\
\hline
\end{tabular}

Sumber: Hasil Olahan Data (2019)

kemasan sebagai atribut yang penting dalam pembelian produk Selada Romaine hidroponik. Sedangkan 26 responden memilih atribut kesegaran dan 29 responden memilih atribut kebersihan sebagai atribut yang sangat penting dalam pembelian produk Selada Romaine hidroponik. Hal tersebut dikarenakan atribut kesegaran dan kebersihan faktor utama dalam menentukan kualitas produk sayuran.

\section{b. Tingkat kepuasan konsumen}

Analisis tingkat kepuasan konsumen terhadap produk Selada Romaine dan produk pembanding yaitu Selada Romaine hidroponik UMKM Tunas Urban Farming, merupakan tahap selanjutnya setelah analisis tingkat kepentingan. Analisis tingkat kepuasan bertujuan untuk mengetahui sejauh mana konsumen merasa puas atau harapan terhadap produk telah terpenuhi. Tingkat kepentingan konsumen terhadap Selada Romaine hidroponik dapat diukur menggunakan skala likert. Tabel 5 menunjukkan hasil dari tingkat kepuasan pada masing-masing atribut.

Berdasarkan Tabel 5 dapat diketahui bahwa Selada Romaine hidroponik UMKM Kebun Sayur Surabaya dan UMKM Tunas Urban Farming memiliki tingkat kepuasan yang sama yaitu nilai 4
Tabel 5. Tingkat Kepuasan Konsumen Terbanyak pada Selada Romaine Hidroponik UMKM Kebun Sayur Surabaya dan Tunas Urban Farming Surabaya

\begin{tabular}{lcc}
\hline $\begin{array}{c}\text { Atribut Selada } \\
\text { Romaine }\end{array}$ & \multicolumn{2}{c}{ UMKM } \\
Kebun Sayur & UMKMan Farming \\
\hline Harga & 4 & 4 \\
Bentuk & 4 & 4 \\
Kesegaran & 4 & 4 \\
Kebersihan & 4 & 4 \\
Warna & 4 & 4 \\
Kemasan & 4 & 4 \\
\hline
\end{tabular}

Sumber: Hasil Olahan Data (2019)

atau puas. Responden merasa puas dengan produk dari masing-masing perusahaan karena mereka memiliki kelebihan dan kekurangannya. Harga Selada Romaine UMKM Kebun Sayur yaitu Rp 5.000 per ons sedangkan harga produk pembanding yaitu Rp 4.000 per ons. Namun perbedaan harga tersebut tidak menjadi masalah bagi responden, karena harga tersebut sudah sesuai dengan kualitas produk masingmasing. Beberapa responden menilai bahwa bentuk dari sayuran yang ditawarkan sudah terbilang baik karena sayuran memiliki bentuk yang utuh (akar tidak terlepas, daun tidak kuning, berlubang dan bercak coklat). Namun dari hasil produksi kedua perusahaan tersebut, Tunas Urban Farming memiliki keunggulan pada bagian bentuk sayur. Perusahaan pembanding menggunakan greenhouse pada proses produksi, sehingga dapat meminimalisir adanya penyakit mata kodok atau bercak coklat. Responden juga menilai bahwa produk kedua perusahaan tersebut sudah memiliki kesegaran sayur yang baik. Namun produk pembanding memiliki tingkat kesegaran yang lebih rendah dibandingkan produk UMKM Kebun Sayur. Selada Romaine yang dihasilkan oleh Tunas Urban Farming memiliki kesegaran yang terbilang cukup, karena sayur terlihat sedikit layu akibat 
dari kekurangan nutrisi dan $\mathrm{pH}$ yang kurang cocok. Responden merasa puas terhadap atribut kebersihan, warna dan kemasan yang digunakan oleh kedua perusahaan tersebut dan dinilai sudah baik. Kedua perusahaan tersebut menggunakan kemasan plastik yang dibentuk terbuka seperti bucket.

\section{c. Nilai target}

Nilai target ditentukan dengan menggunakan acuan skala likert seperti dalam tingkat kepuasan dan kepentingan. Tabel 6 menyajikan perbandingan antara nilai tingkat kepuasan produk Selada Romaine hidroponik dengan nilai target

Tabel 6. Penentuan Nilai Target (Goal) Selada Romaine Hidroponik UMKM Kebun Sayur Surabaya

\begin{tabular}{lccc}
\hline $\begin{array}{c}\text { Atribut } \\
\text { Selada } \\
\text { Romaine }\end{array}$ & $\begin{array}{c}\text { Tingkat } \\
\text { Kepuasan }\end{array}$ & Goal & Keterangan \\
\hline Harga & 4 & 4 & Pertahankan \\
Bentuk & 4 & 4 & Pertahankan \\
Kesegaran & 4 & 4 & Pertahankan \\
Kebersihan & 4 & 4 & Pertahankan \\
Warna & 4 & 4 & Pertahankan \\
Kemasan & 4 & 4 & Pertahankan \\
\hline
\end{tabular}

Sumber: Hasil Olahan Data (2019)

atau goal.

Berdasarkan Tabel 6 dapat diketahui tingkat kepuasan dari produk Selada Romaine hidroponik UMKM Kebun Sayur Surabaya, nilai target atau goal serta keterangan dari kedua nilai tersebut. Berdasarkan semua atribut, mulai dari harga sampai dengan kemasan memiliki nilai 4 pada tingkat kepuasan dan nilai goal 4 sehingga keenam atribut tersebut harus dipertahankan.

\section{d. Titik penjualan}

Titik penjualan yang ditetapkan pada penelitian ini yaitu berupa nilai 1,0 apabila atribut tidak menolong dalam penjualan atau atribut memberikan daya tarik yang lemah (tanpa titik penjualan), nilai 1,2 apabila atribut cukup menolong dalam penjualan atau atribut memberikan daya tarik sedang (titik penjualan rendah, dan 1,5 apabila atribut menolong dalam penjualan atau atribut memberikan daya

Tabel 7. Nilai Tingkat Penjualan Terbanyak Selada Romaine Hidroponik UMKM Kebun Sayur Surabaya

\begin{tabular}{lccc}
\hline $\begin{array}{l}\text { Atribut } \\
\text { Selada }\end{array}$ & $\begin{array}{c}\text { Tingkat } \\
\text { Penjualan }\end{array}$ & $\begin{array}{c}\text { Jumlah } \\
\text { (orang) }\end{array}$ & $\begin{array}{c}\text { Persen- } \\
\text { tase (\%) }\end{array}$ \\
Romaine & & & \\
\hline Harga & 1,2 & 16 & 40,0 \\
Bentuk & 1,2 & 20 & 50,0 \\
Kesegaran & 1,5 & 32 & 80,0 \\
Kebersihan & 1,5 & 30 & 75,0 \\
Warna & 1,5 & 21 & 52,5 \\
Kemasan & 1,2 & 29 & 72,5 \\
\hline Sumber: Hasil Olahan Data (2019) \\
tarik yang kuat (titik penjualan kuat). \\
Berdasarkan Tabel 7 diketahui atribut \\
harga, bentuk, dan kemasan memiliki daya \\
tarik yang sedang. Disisi lain, atribut \\
kesegaran, kebersihan dan warna memiliki \\
daya tarik yang kuat. Hal tersebut \\
dikarenekan atribut kesegaran, kebersihan \\
dan warna merupakan tolok ukur dalam \\
menentukan kualitas produk sayuran. \\
Selain itu kesegaran, kebersihan dan warna \\
yang disediakan oleh perusahaan juga \\
dapat menarik perhatian konsumen untuk \\
membeli produk sehingga sangat \\
mempengaruhi dalam penjualan produk. \\
e. Nilai rasio perbaikan \\
Rasio perbaikan digunakan untuk \\
menunjukkan besarnya perubahan atau \\
perbaikan yang harus dilakukan untuk \\
pengembangan produk Selada Romaine \\
hidroponik. Tabel 8 menyajikan rasio \\
perbaikan produk
\end{tabular}


Tabel 8. Nilai Rasio Perbaikan Selada Romaine Hidroponik UMKM Kebun Sayur Surabaya

\begin{tabular}{|c|c|}
\hline $\begin{array}{c}\text { Atribut Selada } \\
\text { Romaine }\end{array}$ & Rasio Perbaikan \\
\hline Harga & 1,0 \\
\hline Bentuk & 1,0 \\
\hline Kesegaran & 1,0 \\
\hline Kebersihan & 1,0 \\
\hline Warna & 1,0 \\
\hline Kemasan & 1,0 \\
\hline
\end{tabular}

Sumber: Hasil Olahan Data (2019)

Menurut Wicaksono (2013), nilai improvement ratio $<1$ memiliki arti tidak ada perubahan, 1-1,5 memiliki arti perbaikan sedang.

f. Nilai bobot dan bobot normal

Tahap selanjutnya yaitu penentuan nilai bobot (raw weight) pada produk Selada Romaine hidropoik UMKM Kebun Sayur Surabaya. Menurut Wicaksono (2013) penentuan nilai bobot (raw weight) dan nilai bobot normal (normalized raw weight) digunakan untuk menunjukkan besarnya perbaikan suatu kriteria harapan konsumen. Tabel 9 menyajikan nilai bobot

Tabel 9. Nilai Bobot (Raw Weight) dan Bobot Normal (Normalized Raw weight) Selada Romaine Hidroponik UMKM Kebun Sayur Surabaya

\begin{tabular}{lccc}
\hline $\begin{array}{c}\text { Atribut } \\
\text { Selada } \\
\text { Romaine }\end{array}$ & $\begin{array}{c}\text { Nilai } \\
\text { Bobot }\end{array}$ & $\begin{array}{c}\text { Nilai Bobot } \\
\text { Normal }\end{array}$ & Prioritas \\
\hline Harga & 4,8 & 0,14 & 3 \\
Bentuk & 4,8 & 0,14 & 3 \\
Kesegaran & 7,5 & 0,21 & 1 \\
Kebersihan & 7,5 & 0,21 & 1 \\
Warna & 6 & 0,17 & 2 \\
Kemasan & 4,8 & 0,14 & 3 \\
\hline
\end{tabular}

Sumber: Hasil Olahan Data (2019) produk Selada Romaine Hidroponik.

Berdasarkan dari nilai bobot normal yang dihasilkan, dapat diartikan bahwa untuk atribut kesegaran dan kebersihan merupakan atribut yang menjadi prioritas utama untuk memuaskan konsumen. Sehingga perusahaan harus memprioritaskan perbaikan dan peningkatan kualitas terhadap atribut tersebut.

\section{3) Respon Teknik}

Bedasarkan hasil identifikasi suara atau harapan dari konsumen pada produk Selada Romaine hidroponik UMKM Kebun Sayur Surabaya, perusahaan dapat membuat respon teknik sebagai tanggapan suara konsumen yang disajikan pada Tabel 10.

\section{4) Matriks Hubungan}

Hubungan yang terjadi antara harapan konsumen dengan respon teknik perusahaan dapat berupa hubungan yang kuat $(\bullet)$, sedang $(\circ)$, lemah $(\Delta)$ atau tidak memiliki hubungan sama sekali. Berdasarkan hasil wawancara dengan Manajer UMKM Kebun Sayur Surabaya, hubungan antara kedua persyaratan dalam matriks hubungan dapat dilihat pada Tabel 11.

\section{5) Korelasi Teknik}

Hubungan yang terjadi antar respon teknik dapat berupa hubungan positif kuat $(++)$, positif lemah $(+)$, negatif kuat (--), negatif lemah (-) dan tidak memiliki hubungan sama sekali. Berdasarkan hasil wawancara dengan manajer UMKM Kebun Sayur Surabaya dapat diketahui hubungan antar respon teknik dan dapat dilihat pada Tabel 12.

\section{6) Matriks Teknik}

a. Prioritas dan kontribusi

Nilai prioritas memiliki arti bahwa semakin besar nilai prioritas maka semakin besar pula kontribusi respon teknik tersebut dalam memenuhi kepuasan konsumen (Andriantantri, 2008). Sedang- 
Tabel 10. Respon Teknik UMKM Kebun Sayur Surabaya terhadap Harapan Konsumen

\begin{tabular}{|c|c|c|}
\hline No. & Suara atau Harapan Konsumen & Respon Teknik (hows) \\
\hline & Harga produk Rp 4.000 per ons & $\begin{array}{l}\text { Mempertimbangkan dan menyesuaikan harga } \\
\text { dengan atribut yang lain }\end{array}$ \\
\hline & $\begin{array}{l}\text { Bentuk sayuran utuh atau tidak } \\
\text { terdapat bercak cokelat pada daun, } \\
\text { daun tidak berlubang, daun tidak } \\
\text { menguning, serta akar tidak terlepas } \\
\text { dari tanaman }\end{array}$ & $\begin{array}{l}\text { Melakukan perbaikan pada kegiatan sortasi agar } \\
\text { produk Selada Romaine yang siap jual memiliki } \\
\text { bentuk utuh }\end{array}$ \\
\hline & $\begin{array}{l}\text { Kesegaran tanaman yaitu sangat segar } \\
\text { atau fresh hasil panen }\end{array}$ & Mempertahankan kesegaran Selada Romaine \\
\hline & Kebersihan sayuran sangat higienis & $\begin{array}{l}\text { Melakukan pencucian pada hasil panen agar } \\
\text { Selada Romaine lebih higienis atau bersih dari } \\
\text { kotoran }\end{array}$ \\
\hline & $\begin{array}{l}\text { Warna sayuran hijau segar atau tidak } \\
\text { terlalu tua dan muda }\end{array}$ & $\begin{array}{l}\text { Mempertahankan warna sayuran dengan } \\
\text { mengontrol proses budidaya }\end{array}$ \\
\hline & Kemasan plastik terbuka seperti bucket & $\begin{array}{l}\text { Mempertahankan jenis kemasan yaitu plastik } \\
\text { terbuka seperti bucket }\end{array}$ \\
\hline
\end{tabular}

Sumber: Hasil Olahan Data (2019)

Tabel 11. Matriks Hubungan Harapan Konsumen dengan Respon Teknik

\begin{tabular}{|c|c|c|c|c|c|c|c|}
\hline $\begin{array}{l}\text { Respon } \\
\text { Teknik }\end{array}$ & 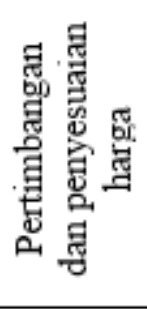 & 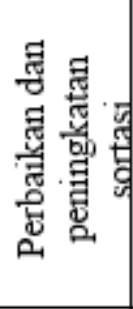 & 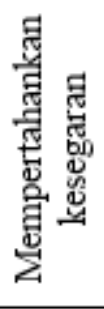 & 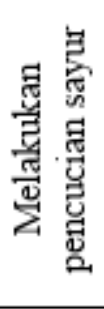 & 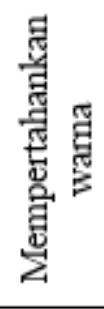 & 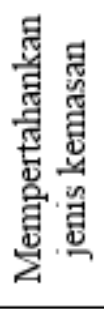 & 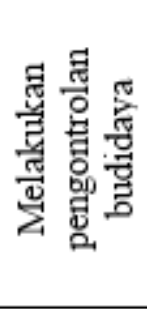 \\
\hline Harga & $\bullet$ & & & $\Delta$ & & $\bullet$ & \\
\hline Bentuk & & $\bullet$ & & & & $\Delta$ & $\bullet$ \\
\hline Kesegaran & & 0 & $\bullet$ & $\Delta$ & $\bullet$ & $\bullet$ & $\bullet$ \\
\hline Kebersihan & & $\bullet$ & & $\bullet$ & & 0 & \\
\hline Warna & & 0 & $\bullet$ & & $\bullet$ & & $\bullet$ \\
\hline Kemasan & $\bullet$ & & $\bullet$ & & & $\bullet$ & \\
\hline
\end{tabular}

Sumber: Hasil Olahan Data (2019)

kan nilai kontribusi memiliki arti bahwa suatu nilai yang berisi ukuran dan prioritas, artinya semakin besar nilai kontribusi maka respon teknik tersebut perlu didahulukan dalam perbaikan. Adapaun nilai prioritas dan kontribusi dapat dilihat pada Tabel 13.

\section{b. Benchmarking}

Benchmarking merupakan proses untuk mengukur kinerja terhadap perusahaan yang terbaik dalam kelasnya, kemudian dianalisis untuk memenuhi dan melebihi dari perusahaan tersebut. Adapun hasil dari perhitungan benchmarking disajikan pada Tabel 14.

Berdasarkan Tabel 14 dapat diketahui bahwa nilai benchmarking yang dimiliki oleh UMKM Kebun Sayur dan UMKM Tunas Urban Farming adalah sama atau 
Tabel 12. Korelasi Teknik UMKM Kebun Sayur Surabaya

\begin{tabular}{|c|c|c|c|c|c|c|c|}
\hline $\begin{array}{l}\text { Respon } \\
\text { Teknik }\end{array}$ & 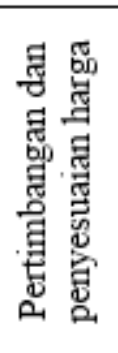 & 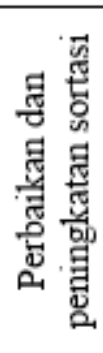 & 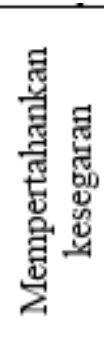 & 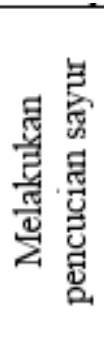 & 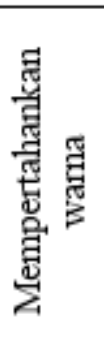 & 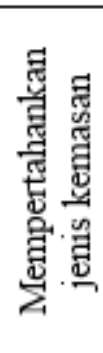 & 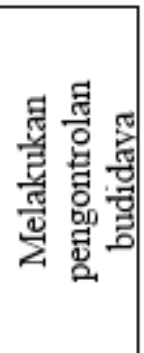 \\
\hline $\begin{array}{c}\text { Pertimbangan dan } \\
\text { penyesuaian } \\
\text { harga }\end{array}$ & & + & & + & & ++ & \\
\hline $\begin{array}{c}\text { Perbaikan dan } \\
\text { peningkatan } \\
\text { sortasi }\end{array}$ & & & + & & & & \\
\hline $\begin{array}{c}\text { Mempertahankan } \\
\text { kesegaran }\end{array}$ & & & & + & H & ++ & ++ \\
\hline $\begin{array}{c}\text { Melakukan } \\
\text { pencucian sayur }\end{array}$ & & & & & & & \\
\hline $\begin{array}{c}\text { Mempertahankan } \\
\text { Warna }\end{array}$ & & & & & & & ++ \\
\hline $\begin{array}{c}\text { Mempertahankan } \\
\text { jenis kemasan }\end{array}$ & & & & & & & \\
\hline $\begin{array}{c}\text { Melakukan } \\
\text { pengontrolan } \\
\text { budidaya }\end{array}$ & & & & & & & \\
\hline
\end{tabular}

Sumber: Hasil Olahan Data (2019)

Tabel 13. Nilai Prioritas dan Kontribusi Produk Selada Romaine Hidroponik UMKM Kebun Sayur Surabaya

\begin{tabular}{clcc}
\hline No. & \multicolumn{1}{c}{ Respon Teknik } & Prioritas & Kontribusi \\
\hline 1. & Pertimbangan dan penyesuaian harga & 2,52 & 0,09 \\
2. & Perbaikan dan peningkatan sortasi & 4,29 & 0,16 \\
3. & Mempertahankan kesegaran & 4,68 & 0,17 \\
4. & Melakukan pencucian sayur & 2,24 & 0,08 \\
5. & Mempertahankan warna & 3,42 & 0,13 \\
6. & Mempertahankan jenis kemasan & 5,18 & 0,19 \\
7. & Melakukan pengontrolan budidaya & 4,68 & 0,17 \\
\hline & Total & 27,01 & 0,99 \\
\hline
\end{tabular}

Sumber: Hasil Olahan Data (2019) 
Tabel 14. Nilai Benchmarking Produk Selada Romaine Hidroponik UMKM Kebun Sayur dan UMKM Tunas Urban Farming

\begin{tabular}{llcc}
\hline No. & \multicolumn{1}{c}{ Respon Teknik } & $\begin{array}{c}\text { UMKM Kebun } \\
\text { Sayur }\end{array}$ & $\begin{array}{c}\text { UMKM Tunas Urban } \\
\text { Farming }\end{array}$ \\
\hline 1. & Pertimbangan dan penyesuaian harga & 4 & 4 \\
2. & Perbaikan dan peningkatan sortasi & 4 & 4 \\
3. Mempertahankan kesegaran & 4 & 4 \\
4. & Melakukan pencucian sayur & 4 & 4 \\
5. Mempertahankan warna & & 4 \\
6. Mempertahankan jenis kemasan & 4 & 4 \\
7. & Melakukan pengontrolan budidaya & 4 & 4 \\
\hline
\end{tabular}

Sumber: Hasil Olahan Data (2019)

Tabel 15. Nilai Target Produk Selada Romaine Hidroponik UMKM Kebun Sayur

\begin{tabular}{|c|c|c|c|c|}
\hline \multirow{2}{*}{ No. } & \multirow{2}{*}{ Respon Teknik } & \multicolumn{2}{|c|}{ Nilai } & \multirow{2}{*}{ Keterangan } \\
\hline & & Benchmarking & Target & \\
\hline & Pertimbangan dan penyesuaian harga & 4 & 4 & Dipertahankan \\
\hline & Perbaikan dan peningkatan sortasi & 4 & 4 & Dipertahankan \\
\hline & Mempertahankan kesegaran & 4 & 4 & Dipertahankan \\
\hline & Melakukan pencucian sayur & 4 & 4 & Dipertahankan \\
\hline & Mempertahankan warna & & 4 & Dipertahankan \\
\hline & Mempertahankan jenis kemasan & 4 & 4 & Dipertahankan \\
\hline 7. & Melakukan pengontrolan budidaya & 4 & 4 & Dipertahankan \\
\hline
\end{tabular}

Sumber: Hasil Olahan Data (2019)

bernilai 4 pada setiap respon tekniknya. Hal ini mempunyai arti bahwa nilai respon yang dimiliki oleh kedua perusahaan tersebut sama baiknya.

\section{c. Target}

Nilai target menyatakan perbandingan antara produk yang diteliti yaitu Selada Romaine hidroponik UMKM Kebun Sayur Surabaya dengan produk UMKM Tunas Urban Farming. Target ditentukan dengan mengevaluasi penilaian dari setiap respon teknik dan membuat pilihan baru untuk mempertahankan produk agar tidak berubah dan membuat produk lebih baik lagi dari pesaingnya. Nilai target diambil dari nilai benchmarking terbesar pada kedua perusahaan.

Berdasarkan Tabel 15 dapat diketahui bahwa nilai benchmarking dari UMKM
Kebun sayur Surabaya pada setiap respon tekniknya adalah sama dengan target 4 . Adanya nilai yang sama dapat disimpulkan bahwa respon teknik perlu dipertahankan untuk memenuhi kebutuhan konsumen. Setelah melakukan semua tahapan, maka selanjutnya yaitu penyusunan House of Quality yang dapat dilihat pada Ilustrasi 6.

\section{KESIMPULAN}

Berdasarkan hasil penelitian, diketahui jenis kecacatan yang sering terjadi pada produk yaitu kondisi daun cacat sebesar $85 \%$ dibandingkan dengan akar terlepas dari tanaman sebesar $15 \%$. Nilai kecacatan produk Selada Romaine diketahui berada di luar batas kendali, dikarenakan terdapat 5 titik berada di atas garis UCL dan 5 titik di bawah garis LCL. 


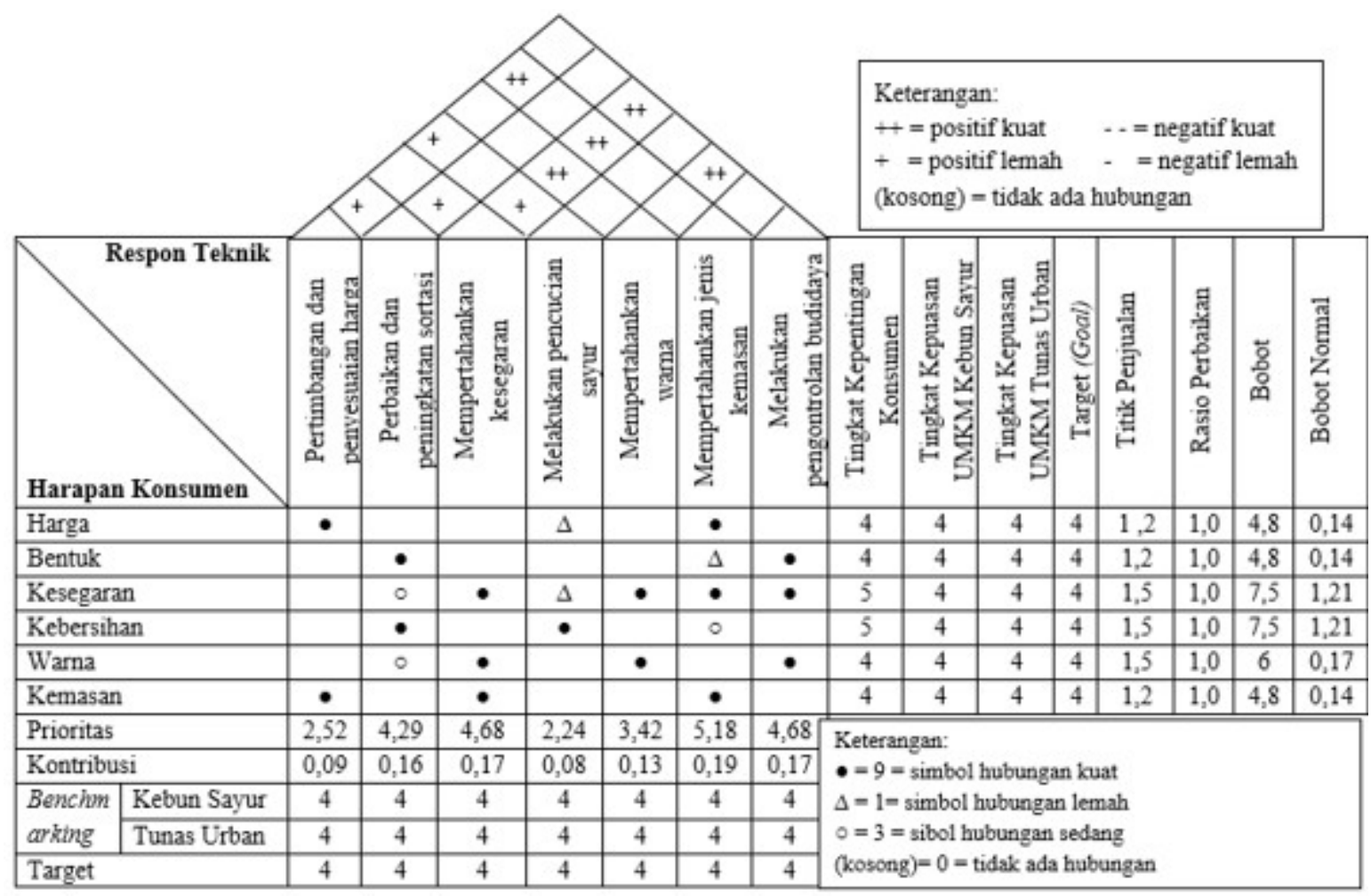

Ilustrasi 6. House of Quality (HoQ) Selada Romaine UMKM Kebun Sayur Surabaya

Faktor-faktor yang menyebabkan kecacatan produk Selada Romaine yaitu faktor mesin, manusia, lingkungan dan metode. Akar penyebab atau permasalahan yaitu faktor mesin (tidak menggunakan greenhouse) dan faktor manusia (human error). Sehingga usulan perbaikan yang diberikan yaitu pembuatan greenhouse minimal tutupan seperti pada bagian persemaian dan mengadakan pelatihan hidroponik.

Harapan konsumen terhadap produk Selada Romaine yaitu harga produk $\mathrm{Rp} 4.000$ per ons; bentuk produk utuh; kesegaran produk fresh hasil panen; kebersihan produk sangat higienis; warna produk hijau segar; serta kemasan produk yaitu plastik terbuka seperti bucket bunga. Respon teknik yang diberikan oleh perusahaan yaitu mempertimbangkan dan menyesuaikan harga dengan atribut lain; melakukan perbaikan pada kegiatan sortasi; mempertahankan kesegaran produk; melakukan pencucian hasil panen; mempertahankan warna produk; serta mempertahankan jenis kemasan. Berdasarkan bobot normal harapan konsumen, atribut yang perlu diprioritaskan yaitu kesegaran dan kebersihan. Sedangkan nilai prioritas respon teknik yang perlu diprioritaskan yaitu mempertahankan jenis kemasan.

\section{SARAN}

UMKM Kebun Sayur Surabaya disarankan untuk melakukan perbaikan kualitas dengan memfokuskan perbaikan pada jenis kecacatan yang dominan. Selain itu untuk meminimalisir kecacatan berdasarkan faktor penyebab, dapat dilakukan tindakan perbaikan berupa penggunaan greenhouse serta melakukan pelatihan, pengawasan, dan pemantauan terhadap cara kerja karyawan dalam proses produksi Selada Romaine hidroponik.

UMKM Kebun Sayur Surabaya perlu membuat Standar Operasional Prosedur (SOP) secara tertulis, agar proses produksi 
dapat berjalan dengan lancar dan sesuai ketentuan, serta menjaga konsistensi kualitas output dari perusahaan.

UMKM Kebun Sayur Surabaya perlu melakukan survei kepuasan konsumen pada setiap bulannya, agar dapat melakukan evaluasi terhadap produk Selada Romaine hidroponik. Agar produk sesuai dengan harapan konsumen, maka diperlukan perbaikan secara terus-menerus pada kegiatan produksi.

\section{DAFTAR PUSTAKA}

Amanah, D. 2017. Pengaruh harga dan kualitas produk terhadap kepuasan konsumen pada Majestyk Bakery \& Cake Shop Cabang H.M. Yamin Medan. J. Keuangan dan Bisnis. 2(1) : 71-87.

Badan Pusat Statistik. 2017. Statistik Tanaman Sayuran dan Buah-buahan Semusim Indonesia 2016. BPS, Jakarta.

Badan Pusat Statistik. 2018. Perkembangan Ekspor dan Impor Indonesia Agustus 2018. BPS, Jakarta.

Heizer, J., dan B. Render. 2016. Manajemen Operasi, Ed. 11. Salemba Empat, Jakarta.

Jacobs, F. R. dan R. B. Chase. 2015. Manajemen Operasi dan Rantai Pasokan. Salemba Empat, Jakarta.

Kementrian Pertanian. 2015. Statistik Produksi Hortikultura Tahun 2014. Direktorat Jenderal Hortikultura, Kementrian Pertanian, Jakarta.

Kementrian Pertanian. 2018. Ekspor Buah, Sayuran dan Bunga Indonesia Tembus 29 Negara. Kementrian Pertanian. https://www.pertanian.go.id/home/?show $=$ news\&act $=$ view\&id $=1967$ diakses pada 25 November 2018.

Kontan.co.id. 2018. Ekspor Produk Pertanian Indonesia pada Agustus 2018 Anjlok 20.98\%. https://businessinsight.kontan. co.id/news/ekspor-produk-pertanian- indonesia-pada-agustus-2018-anjlok$\underline{2098}$ diakses pada 21 Februari 2019.

Krajewski, L. J., L. P. Ritzman, dan M. K. Malhotra. 2013. Operations Management. Pearson Education Limited, Halow.

Nunes, J. 2015. Strategi pengembangan usaha tani sayuran berorientasi pasar modern (Studi Kasus Kelompok Tani Liudiak Desa Liurai Distrik Aileu Timor Leste). J. Ilmu Pertanian dan Peternakan. 3(1) : 19.

Prasojo, M. 2017. Peluang Bisnis Sayuran Hidroponik. https://unsurtani.com/2017/ 04/peluang-bisnis-sayuran-hidroponikdan-strategi-pemasarannya diakses pada 18 Maret 2019.

Sekaran, U. 2003. Research Methods for Business, 4th Ed. John Wiley and Sons, Inc, New York.

Setiawan, H. 2017. Kiat Sukses Budidaya Cabai Hidroponik. Bio Genesis, Yogyakarta.

Stevenson, W. J. dan S. C. Chuong. 2014. Manajemen Operasi Perspektif Asia. Salemba Empat, Jakarta.

Sugiyono. 2018. Metode Penelitian Kuantitatif, Kualitatif, dan R\&D. Alfabeta, Bandung.

Weenas, J. R. 2013. Kualitas produk, harga, promosi dan kualitas pelayanan pengaruhnya terhadap keputusan pembelian Springbed Comforta. J. EMBA. 1(4) : 607-618.

Wijaya, D. T. 2018. Manajemen Kualitas Jasa Desain Servqual, QFD, dan Kano. Indeks Jakarta, Jakarta.

Yuarini, D. A. A., I. K. Satriawan, dan I. D. P. O. Suardi. 2015. Strategi peningkatan kualitas produk sayuran segar organik pada CV. Golden Leaf Farm Bali. J. Manajemen Agribisnis. 3(2) : 93-109. 
